\title{
Body composition and bone mineral density in women with Cushing's syndrome in remission and the association with common genetic variants influencing glucocorticoid sensitivity
}

\author{
Oskar Ragnarsson 1,+, Camilla A M Glad, Ragnhildur Bergthorsdottir, \\ Erik G Almqvist ${ }^{1}$, Eva Ekerstad ${ }^{2}$, Håkan Widell ${ }^{3}$, Bo Wängberg ${ }^{4}$ and \\ Gudmundur Johannsson
}

Institute of Medicine at Sahlgrenska Academy, University of Gothenburg, Göteborg, Sweden, 'Department of Endocrinology, Skaraborg Hospital, Skövde, Sweden, 'Department of Internal Medicine, Norra Älvsborgs Hospital, Trollhättan, Sweden, ${ }^{3}$ Department of Internal Medicine, Södra Älvsborgs Hospital, Borås, Sweden and ${ }^{4}$ Department of Surgery, Sahlgrenska University Hospital, Sahlgrenska Academy, University of Gothenburg, Göteborg, Sweden ${ }^{\dagger}$ O Ragnarsson is now at Department of Endocrinology, Sahlgrenska University Hospital, Gröna Stråket 8, SE-413 45 Göteborg, Sweden

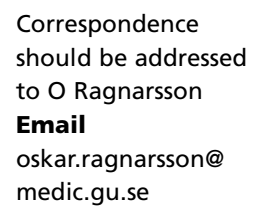

\begin{abstract}
Objective: Adverse body compositional features and low bone mineral density (BMD) are the characteristic of patients with active Cushing's syndrome (CS). The aim of this study was to evaluate body composition and BMD in women with $\mathrm{CS}$ in long-term remission and the influence of polymorphisms in genes affecting glucocorticoid (GC) sensitivity on these end-points.

Design, patients and methods: This was a cross-sectional, case-controlled study, including 50 women previously treated for CS and 50 age and gender-matched controls. Median (interquartile range) remission time was 13 (5-19) years. Body composition and BMD were measured with dual-energy X-ray absorptiometry. Five polymorphisms in four genes associated with GC sensitivity were analysed using TaqMan or Sequenom single-nucleotide polymorphism genotyping. Results: Patients with CS in remission had increased abdominal fat mass $(P<0.01)$, whereas BMD was not significantly different at any site between patients and controls. In patients, the $N R 3 C 1 \mathrm{Bcl} 1$ polymorphism was associated with reduced total $(P<0.05)$ and femur neck BMD $(P<0.05)$. The polymorphism rs 1045642 in the $A B C B 1$ gene was associated with increased abdominal fat mass $(P<0.05)$ and decreased appendicular skeletal muscle mass $(P<0.05)$. GC replacement was associated with reduced total BMD $(P<0.01), \mathrm{BMD}$ at lumbar spine $(P<0.05)$ and increased abdominal fat $(P<0.01)$. Conclusion: Ongoing GC replacement therapy together with polymorphisms in two genes related with GC sensitivity is associated with abdominal obesity and adverse skeletal health in patients with CS in long-term remission.
\end{abstract}

\section{Introduction}

Low bone mineral density (BMD) (1), osteoporotic fractures (2), increased fat mass and reduced lean body mass $(\operatorname{LBM})(3,4,5,6)$ are the characteristic features of active Cushing's syndrome (CS). The effect of remission on body composition has been studied prospectively in few studies, all showing reduction in adipose tissue following treatment $(4,7,8,9,10)$. LBM is, however, reported to be unchanged $(4,8,9,10)$, or even reduced after treatment (7). In a recent case-control study in patients with CS in remission, total and abdominal fat mass were increased, (c) 2015 European Society of Endocrinology Printed in Great Britain
Published by Bioscientifica Ltd. 
but LBM was similar in patients as compared with controls (11).

Prospective studies have demonstrated improved BMD following treatment of CS $(12,13,14)$. However, these studies have small numbers of patients, short follow-up time and/or lack a control group. Two studies carried out in patients with CS at long-term remission present conflicting results on bone metabolism, with BMD $Z$-scores being either normal (1) or decreased (15).

The effects of glucocorticoids (GCs) are mediated through the GC receptor. Several polymorphisms in the GC receptor gene (NR3C1) are described that may either increase (BcI1 and N363S) or decrease (ER22/23EK and A3669G) GC sensitivity (16). In patients with active CS, BclI is associated with reduced BMD (17) and A3669G, with a decreased risk of developing diabetes mellitus (18). In addition, polymorphisms in the genes coding for the mineralocorticoid receptor (NR3C2) (19), $11 \beta$-hydroxysteroid dehydrogenase type 1 (HSD11B1) $(20,21)$ and ATP-binding cassette B1 (ABCB1) (22) may also be important for GC sensitivity. Recently, we have demonstrated that polymorphisms in the HSD11B1 and NR3C1 genes are associated with impaired cognitive function in patients with CS in remission (23). The effect of polymorphisms in these genes on body composition and BMD in patients with CS in remission has not been studied.

The aim was to study body composition and BMD in patients with CS in long-term remission. The main hypothesis was that patients with CS in remission have increased fat mass and decreased muscle mass and BMD in comparison with healthy controls. We also hypothesised that polymorphisms in the GC receptor gene, and genes involved in metabolism and transport of GCs, influence the normalisation of body composition and BMD in successfully treated CS patients.

\section{Patients and methods}

\section{Study design}

This was a cross-sectional, case-control study, designed to evaluate long-term outcome in patients previously treated for Cushing's disease (CD) and cortisol-producing adrenal adenomas. The subjects were studied on three occasions where medical history was reviewed, physical examination was performed, hormonal status, fatigue and psychiatric status were evaluated and neuropsychological tests performed as previously described (24). In this part of the study, anthropometry, body composition, BMD and cardiovascular risk factors in 50 women successively treated for CS are presented.

\section{Patients}

The study group for the current analysis consisted of 50 women with CS in remission: patients with ectopic adrenocorticotrophin (ACTH)-producing tumours, subclinical CS, cortisol-producing adrenocortical cancer, uncontrolled $\mathrm{CD}$ and male patients were not included. The mean age at diagnosis was $37 \pm 13$ (mean \pm s.D.) years and $53 \pm 14$ years at follow-up. Thirty-eight patients had been treated for ACTH-producing pituitary adenomas and 12 patients had been operated by unilateral adrenalectomy for cortisol-producing adrenal adenomas. The primary treatment for CD was transsphenoidal pituitary surgery in 26 patients, bilateral adrenalectomy in seven and radiotherapy in five. In patients with CD, 16 (42\%) needed additional treatment due to unsuccessful primary treatment, relapse or progress of remaining pituitary tumour after initial bilateral adrenalectomy. In total, $30(79 \%)$ patients were treated with transsphenoidal pituitary surgery, 12 (32\%) with radiotherapy and 10 (26\%) with bilateral adrenalectomy. Clinical, biochemical, radiological and histopathological data from the time of diagnosis were reviewed to verify that the initial diagnosis of $\mathrm{CD}$ and cortisol-producing adrenal adenoma were correct. Duration of active CS was estimated by reviewing medical records and by asking the patients to estimate for how long they believed that they had had CS before they got the diagnosis. Duration of uncontrolled CS was estimated as the time with active CS in addition to the time from diagnosis until time of remission.

\section{Controls}

Controls to patients were recruited from a random population sample obtained from the Swedish Tax Agency. Potential controls, matched head-to-head for age, gender and educational level, were contacted by an invitation letter.

\section{Evaluation of hormone status}

A 24-h urinary free cortisol (UFC) sampling was carried out and corticotrophin-releasing hormone (CRH) test was performed for evaluation of the hypothalamus-pituitaryadrenal axis as previously described (24). To confirm the remission of CS, a $1 \mathrm{mg}$ overnight dexamethasone suppression test was performed in all patients, except 
those operated with bilateral adrenalectomy $(n=10)$. Serum cortisol concentration $\leq 50 \mathrm{nmol} / 1$ following dexamethasone administration was considered to be an adequate suppression.

Thyroid-, sex hormone and growth hormone (GH) status and the presence or absence of diabetes insipidus were evaluated clinically and by measurements of serum levels of free thyroxine $\left(\mathrm{T}_{4}\right)$, thyrotrophin, oestrogen, DHEAS, androstenedione, gonadotropins and insulin-like growth factor 1 (IGF1). In addition, in patients with suspected GH deficiency, an insulin tolerance test was performed.

\section{Analytical methods}

Serum cortisol was measured using competitive electrochemiluminescence immunoassay (Cortisol Elecsys, Roche Diagnostics Scandinavia AB), UFC using RIA (SpectRia Cortisol 125I, Orion Diagnostica, Espoo, Finland) and serum IGF1 was measured with an immunoenzymometric assay (Immulite 2500 IGF1, DPC/Siemens Medical Solutions Diagnostics Ltd, Llanbeis, Gwynedd, UK). Plasma glucose concentrations were measured using an enzymatic hexokinase method (GLU, Roche/Hitachi; Roche Diagnostics $\mathrm{GmbH}$ ) with a $4 \%$ coefficient of variation (CV) at concentrations between 5 and $15 \mathrm{mmol} / \mathrm{l}$. Total-, LDL- and HDL-cholesterol and triglycerides (TG) in serum were measured by an enzymatic method (Roche Diagnostics $\mathrm{GmbH}$ ). The $\mathrm{CV}$ for total-cholesterol was 3\% at serum concentrations between 4 and $6 \mathrm{mmol} / \mathrm{l}, 4 \%$ for LDL at concentrations between 2 and $5 \mathrm{mmol} / \mathrm{l}, 5 \%$ for HDL-cholesterol at concentrations between 1 and $2 \mathrm{mmol} / \mathrm{l}$ and $4 \%$ for TG at concentrations between 1 and $2 \mathrm{mmol} / \mathrm{l}$. Whole blood for genetic analysis and serum for the analysis of lipids were stored at $-80^{\circ} \mathrm{C}$ and analysed at the end of the study.

\section{Measurements}

Height was measured with an accuracy of $0.5 \mathrm{~cm}$ and weight $(\mathrm{kg})$ to one decimal place. BMI was calculated as weight $/$ height ${ }^{2}\left(\mathrm{~kg} / \mathrm{m}^{2}\right)$. Waist circumference (WC) was measured in the supine position midway between the iliac crest and the lowest level of the thorax.

Total LBM, total fat mass, abdominal fat mass and BMD were measured using DXA (Lunar DPX-L, 12 Lunar Corporation, Madison, WI, USA). The precision errors (1 s.D.) for fat mass and LBM were 1.7 and $0.7 \%$ respectively. Appendicular skeletal muscle mass (ASMM) was calculated from lean mass in arms and legs obtained from the DXA as previously described (25).
Metabolic syndrome was defined according to the criteria published in 2005 by the International Diabetes Foundation (26). This included WC $>80 \mathrm{~cm}$ and two of the following: i) $\mathrm{TG}>1.7 \mathrm{mmol} / \mathrm{l}$; ii) HDL-cholesterol $<1.3 \mathrm{mmol} / \mathrm{l}$; iii) blood pressure $>130 / 85 \mathrm{mmHg}$ or antihypertensive treatment and iv) f-glucose $>5.6$ or impaired glucose tolerance (IGT) or type 2 diabetes mellitus.

\section{Single-nucleotide polymorphism selection and genetic analyses}

Blood samples for DNA isolation were available from 49 patients. Five single-nucleotide polymorphisms (SNPs) in four genes were analysed; Bcl1 (rs41423247) and A3669G (rs6198) in the NR3C1 gene, I180V (rs5522) in the NR3C2 gene, rs11119328 in the HSD11B1 gene and rs1045642 in the $A B C B 1$ gene. The selection of the candidate genes was based on their previously described effects on GC sensitivity $(16,17,18,19,20,21,22)$. Due to the limited size of our cohort, we chose only SNPs with a minor allele frequency $(\mathrm{MAF})>10 \%$ in the HapMap CEU Panel.

Genomic DNA was isolated using the QIAamp DNA Blood Maxi Kit from Qiagen according to the manufacturer's standard protocol. Genotyping of SNPs Bcl1 (rs41423247), rs6198 and rs1045642 was performed using TaqMan SNP genotyping. The remaining SNPs were genotyped on the Sequenom platform (Sequenom, Inc., San Diego, CA, USA). In the TaqMan SNP genotyping, 20 ng genomic DNA was added to a reaction mix containing $1 \times$ TaqMan Genotyping PCR Master Mix (Applied Biosystems) and SNP-specific genotyping assays purchased from Applied Biosystems (rs6198: C_8951023_10 and rs1045642: C_7586657_20). $\mathrm{Bcl1}$ was genotyped using custom designed primers (Fp: GCT CAC AGG GTT CTT GCC ATA and Rp: TTG CAC CAT GTT GAC ACC AAT) and probes (P1: 6FAM-TCT GCT GAT CAA TCT-MGBNFQ and P2: VIC-TCT GCT GAT GAA TCT-MGBNFQ), with optimised concentrations of primers $(0.9 \mu \mathrm{M})$ and probes $(0.2 \mu \mathrm{M})$. All reactions were carried out in $5 \mu \mathrm{l}$ reactions on 384-well plates (Applied Biosystems). PCR amplification and allele detection were carried out in an ABI Prism 7900HT Sequence Detection System instrument (Applied Biosystems). In the Sequenom analysis, primers for multiplex PCR and extension reactions were designed by the SpectroDesigner Software (Sequenom GmbH). All primer sequences are available on request. PCR and extension reactions were performed according to manufacturer's standard protocols using the Iplex Gold Chemistry and Spectrochips version 2. The SNP analysis was performed by matrix-assisted laser desorption/ionisation-time of flight (MALDI-TOF) mass spectrometry (Sequenom GmbH). 
Each assay was validated using a set of 14 trios families, in a total of 42 individuals. Genotype data from these individuals are available through the HapMap consortium. Concordance analyses with the HapMap data as well as analysis of the parent-offspring compatibility with the produced genotypes were performed.

\section{Ethical considerations}

Informed written consent was obtained from all patients and controls. The Local Ethical Committee of the University of Gothenburg, Göteborg, Sweden, approved the study. The study was conducted according to the Declaration of Helsinki.

\section{Statistical analyses}

All statistical analyses were performed with SPSS, version 17.0 for windows. Data are presented as mean \pm s.D. or median (25-75th percentiles). For comparison between groups, we used unpaired $t$-test for normally distributed data and Mann-Whitney $U$-test for non-normally distributed data. For proportions, Pearson $\chi^{2}$ or Fisher's exact test was used as appropriate.

We also used multiple linear regression models with backward elimination to examine the differences in total and abdominal fat mass, total LBM, ASMM and BMD (total, lumbar spine and proximal femur neck) between patients and controls, while accounting for possible influences of weight, height and serum concentrations of free $\mathrm{T}_{4}$ and DHEAS. In a similar way, logistic regression was used for the analysis of the metabolic syndrome. In patients with CS in remission, same dependent variables were analysed with same adjustments, as well as age, to study the influence of the aetiology of CS (CD vs cortisol-producing adrenal adenoma), time with uncontrolled disease, duration of remission and GC replacement therapy.

The influence of SNPs on total and abdominal fat mass, total LBM, ASMM, BMD (total, lumbar spine and proximal femur neck) and the metabolic syndrome in patients with CS in remission was analysed by multiple linear or logistic regression models after adjustment for age, weight, height, GC treatment, as well as serum concentrations of free $\mathrm{T}_{4}$, DHEAS and IGF1. Due to the limited size of our cohort, carriers of minor alleles (heterozygotes and homozygotes) were analysed as a single group (dominant model). A two-tailed $P$ value of $<0.05$ was considered statistically significant.

\section{Results}

\section{Hormonal status}

At study entry, all patients were in remission. The median (interquartile rage) time in remission was 13 (5-19) years. Nineteen (38\%) patients were receiving GC replacement therapy: ten after bilateral adrenalectomy, seven due to pituitary insufficiency after transsphenoidal pituitary surgery and/or radiotherapy and two after unilateral adrenalectomy. The mean hydrocortisone (HC) dose was $24 \pm 9 \mathrm{mg} /$ day (median 25, range 10-40). UFC did not differ between patients and controls (Table 1). UFC in GC-treated patients was increased compared with GC sufficient patients $(276 \pm 217 \mathrm{nmol} / 24 \mathrm{~h}$ vs $150 \pm 63 \mathrm{nmol} / 24 \mathrm{~h}$; $P<0.05)$. Eight patients had fludrocortisone, all treated with bilateral adrenalectomy.

Eighteen (36\%) patients were on $\mathrm{L}_{-} \mathrm{T}_{4}$ treatment: 13 due to central and five due to primary hypothyroidism. Free $\mathrm{T}_{4}$ value (Table 1) was higher patients who were on $\mathrm{T}_{4}$ treatment $(18.9 \pm 3.6$ vs $15.6 \pm 2.4 \mathrm{pmol} / 1$ in controls; $P<0.01)$.

Nineteen (50\%) patients with CD had confirmed GH deficiency: 18 were on GH replacement therapy and one had discontinued due to side effects. Three additional patients were diagnosed with GH deficiency in this study. Serum IGF1 concentration did not differ between patients and controls (Table 2), but was higher in those on $\mathrm{GH}$ replacement $(197 \pm 108$ vs $130 \pm 51 \mu \mathrm{g} / \mathrm{l} ; P<0.05)$.

Five of 21 premenopausal women ( $<52$ years) were receiving oestrogen and progesterone for hypogonadotropic hypogonadism and two of 29 postmenopausal

Table 1 Hormone measurements in patients with Cushing's syndrome in remission and healthy controls. S-cortisol was measured in the morning, before (baseline (BL)) and after administration of $\mathrm{CRH}$; S-cortisol - peak represents the highest concentration measured after $\mathrm{CRH}$ administration. Data is presented as mean \pm s.D. or median (interquartile range).

\begin{tabular}{|c|c|c|c|}
\hline & Patients $(n=50)$ & $\begin{array}{l}\text { Controls } \\
(n=50)\end{array}$ & $\boldsymbol{P}$ \\
\hline $\begin{array}{l}\text { S-cortisol - BL } \\
(\mathrm{nmol} / \mathrm{l})^{\mathrm{a}}\end{array}$ & $331 \pm 129$ & $306 \pm 107$ & 0.4 \\
\hline $\begin{array}{l}\text { S-cortisol - peak } \\
(\mathrm{nmol} / \mathrm{l})^{\mathrm{a}}\end{array}$ & $558 \pm 144$ & $597 \pm 83$ & 0.2 \\
\hline UFC (nmol/24 h) & $142(114-211)$ & 146 (124-196) & 0.9 \\
\hline Free $\mathrm{T}_{4}(\mathrm{pmol} / \mathrm{l})$ & $16.7 \pm 3.2$ & $15.0 \pm 1.8$ & $<0.01$ \\
\hline IGF1 $(\mu \mathrm{g} / \mathrm{l})$ & $151 \pm 79$ & $147 \pm 63$ & 0.8 \\
\hline DHEAS $(\mu \mathrm{mol} / \mathrm{l})$ & $1.1(0.2-2.3)$ & $2.5(1.7-3.6)$ & $<0.001$ \\
\hline $\begin{array}{l}\text { Androstenedione } \\
(\mathrm{nmnol} / \mathrm{l})\end{array}$ & $3.9 \pm 2.9$ & $4.6 \pm 2.5$ & 0.2 \\
\hline
\end{tabular}

IGF1, insulin-like growth factor 1; UFC, urinary free cortisol.

${ }^{\text {a }} \mathrm{S}$-cortisol levels were analysed only in ACTH-sufficient patients $(n=30)$. 
Table 2 Anthropometry, body composition and BMD in 50 women with Cushing's syndrome in remission and 50 healthy controls matched for age and gender. Data is presented as mean \pm s.D.

\begin{tabular}{|c|c|c|c|}
\hline & Patients & Controls & $\boldsymbol{P}$ \\
\hline Height (cm) & $164.1 \pm 6.2$ & $166.5 \pm 6.2$ & 0.06 \\
\hline Weight (kg) & $73.4 \pm 18.0$ & $70.6 \pm 14.1$ & 0.4 \\
\hline BMI $\left(\mathrm{kg} / \mathrm{m}^{2}\right)$ & $27.3 \pm 6.9$ & $25.6 \pm 5.1$ & 0.14 \\
\hline Waist $(\mathrm{cm})$ & $93.8 \pm 16.0$ & $89.9 \pm 12.1$ & 0.19 \\
\hline Total fat mass $(\mathrm{kg})$ & $28.3 \pm 11.3$ & $26.4 \pm 11.0$ & 0.4 \\
\hline $\begin{array}{l}\text { Total fat mass ( } \% \text { of body } \\
\text { weight) }\end{array}$ & $38.1 \pm 7.7$ & $36.3 \pm 8.6$ & 0.3 \\
\hline Abdominal fat mass $(\mathrm{kg})$ & $15.2 \pm 6.4$ & $13.0 \pm 6.1$ & 0.08 \\
\hline $\begin{array}{l}\text { Abdominal fat mass } \\
\text { ( } \% \text { of body weight) }\end{array}$ & $20.3 \pm 5.3$ & $17.8 \pm 5.5$ & $<0.05$ \\
\hline Total lean body mass $(\mathrm{kg})$ & $41.1 \pm 5.7$ & $41.8 \pm 5.5$ & 0.5 \\
\hline $\begin{array}{l}\text { Total lean body mass } \\
\text { ( } \% \text { of body weight) }\end{array}$ & $58.2 \pm 7.6$ & $60.4 \pm 8.6$ & 0.2 \\
\hline ASMM $(k g)$ & $18.9 \pm 3.0$ & $19.9 \pm 3.3$ & 0.13 \\
\hline $\begin{array}{l}\text { ASMM ( } \% \text { of body } \\
\text { weight) }\end{array}$ & $26.7 \pm 3.7$ & $28.6 \pm 4.4$ & $<0.05$ \\
\hline BMD total $\left(\mathrm{g} / \mathrm{cm}^{2}\right)$ & $1.09 \pm 0.20$ & $1.14 \pm 0.10$ & 0.1 \\
\hline $\begin{array}{l}\text { BMD lumbar spine } \\
\left(\mathrm{g} / \mathrm{cm}^{2}\right)\end{array}$ & $1.10 \pm 0.19$ & $1.13 \pm 0.17$ & 0.4 \\
\hline BMD femur neck $\left(\mathrm{g} / \mathrm{cm}^{2}\right)$ & $0.96 \pm 0.14$ & $0.95 \pm 0.14$ & 0.8 \\
\hline $\begin{array}{l}\text { Osteopaenia/ } \\
\quad \text { osteoporosis }^{\mathrm{a}}, n(\%)\end{array}$ & $20(40) / 6(12)$ & $19(38) / 6(12)$ & 0.9 \\
\hline
\end{tabular}

ASMM, appendicular skeletal muscle mass; BMD, bone mineral density. ${ }^{a}$ Osteopaenia was defined as $T$-score between -1.0 and -2.5 and osteoporosis as $T$-score $\leq-2.5$ at any site.

women were on oral oestrogen treatment. Two women received replacement with DHEA. Patients had lower DHEAS than controls (Table 2). Two patients had diabetes insipidus. Nine (23\%) patients with CD had no detectable pituitary insufficiency.

\section{Body composition}

Patients with CS in remission tended to be shorter and to have higher BMI than that of the controls, although the differences did not reach statistical significance (Table 2). Patients with CS in remission had higher proportion of abdominal fat mass and decreased proportion of ASMM (Fig. 1 and Table 2). No difference in weight, LBM or total fat mass was seen between the groups.

In a regression analysis, after adjustment for weight, height and serum concentrations of free $\mathrm{T}_{4}$ and DHEAS, CS in remission was independently associated with higher abdominal fat mass ( $B$ 1.2, 95\% CI $0.2-2.3, P=0.03$ ). After same adjustments, the reduced ASMM in patients did not remain significant $(P=0.3)$.

\section{Bone mineral density}

Thirteen patients with CS in remission and two controls received treatment for osteoporosis $(P<0.05)$. Eight patients were taking calcium and vitamin $\mathrm{D}$ supplementation and five calcium, vitamin D and bisphosphonates. One control was receiving calcium and vitamin D supplements and another control received bisphosphonates.

No difference in BMD was observed between patients and controls, total BMD neither total BMD, BMD at lumbar spine nor femur neck (Table 2). Exclusion of subjects on bisphosphonates did not change the results.

\section{Cardiovascular risk factors}

Fifteen patients and seven controls had treatment for hypertension $(P=0.06)$. Patients with $C S$ in remission tended to have higher diastolic blood pressure compared with controls $(P=0.07)$, but systolic blood pressure was not different (Table 3).

Three patients, but no controls, had diabetes mellitus and were on anti-diabetic treatment $(P=0.2)$. The concentrations of fasting plasma glucose were similar in patients and controls (Table 3 ).

Eight patients and three controls were on lipidlowering treatment $(P=0.2)$. After adjustment for weight, serum concentrations of HDL-cholesterol were lower $(P<0.001)$ and TG were higher $(P<0.001)$ in patients
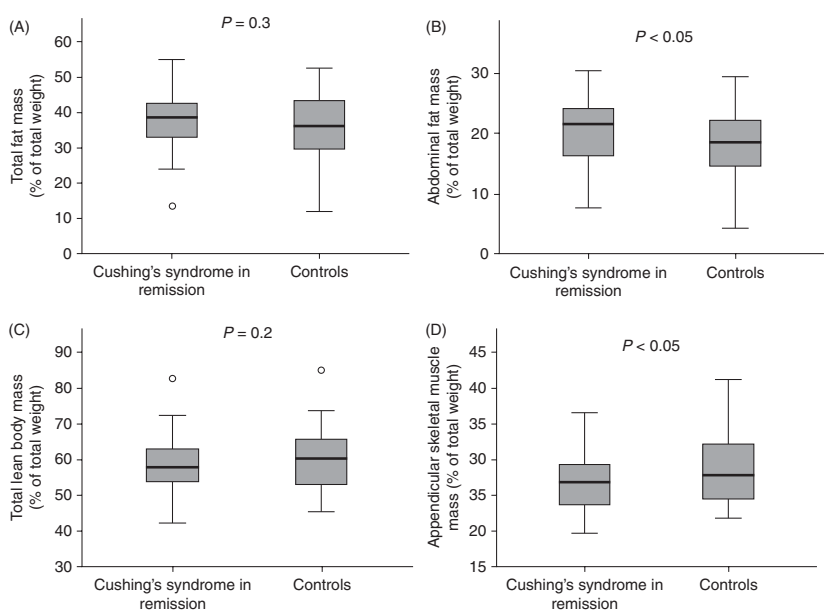

\section{Figure 1}

Box plots showing proportions of total weight (\%) for $(A)$ total fat mass, (B) abdominal fat mass, (C) total lean body mass and (D) appendicular skeletal muscle mass in 50 women with Cushing's syndrome in remission and 50 age- and gendermatched controls. 
Table 3 Cardiovascular risk factors in 50 women with Cushing's syndrome in remission and 50 healthy controls matched for age and gender. Data is presented as mean \pm s.D. or median (interquartile range).

\begin{tabular}{|c|c|c|c|}
\hline & Patients & Controls & $\boldsymbol{P}$ \\
\hline $\begin{array}{l}\text { Systolic blood pressure } \\
(\mathrm{mmHg})\end{array}$ & $127 \pm 20$ & $123 \pm 19$ & 0.3 \\
\hline $\begin{array}{l}\text { Diastolic blood pressure } \\
(\mathrm{mmHg})\end{array}$ & $78 \pm 10$ & $74 \pm 10$ & 0.07 \\
\hline $\begin{array}{l}\text { Treatment for } \\
\quad \text { hypertension, } n(\%)\end{array}$ & $15(30)$ & $7(13)$ & 0.06 \\
\hline $\begin{array}{l}\text { Fasting plasma glucose } \\
(\mathrm{mmol} / \mathrm{l})\end{array}$ & $5.0 \pm 1.2$ & $5.0 \pm 0.6$ & 0.7 \\
\hline $\begin{array}{l}\text { Treatment for diabetes } \\
\text { mellitus, } n(\%)\end{array}$ & $3(6)$ & 0 & 0.2 \\
\hline $\begin{array}{l}\text { Total cholesterol } \\
(\mathrm{mmol} / \mathrm{l})\end{array}$ & $5.1 \pm 1.0$ & $5.0 \pm 0.9$ & 0.7 \\
\hline LDL-cholesterol (mmol/l) & $3.3 \pm 0.9$ & $3.1 \pm 0.9$ & 0.6 \\
\hline HDL-cholesterol (mmol/l) & $1.1 \pm 0.3$ & $1.5 \pm 0.4$ & $<0.001$ \\
\hline TG $(\mathrm{mmol} / \mathrm{l})$ & $1.2(0.9-1.6)$ & $0.8(0.6-1.2)$ & $<0.001$ \\
\hline $\begin{array}{l}\text { Treatment for } \\
\quad \text { dyslipidaemia, } n(\%)\end{array}$ & $8(15)$ & $3(6)$ & 0.2 \\
\hline $\begin{array}{l}\text { Metabolic syndrome, } \\
n(\%)\end{array}$ & $26(53)$ & $12(24)$ & $<0.01$ \\
\hline
\end{tabular}

than in controls (Table 3). The concentrations of totaland LDL-cholesterol were not different.

Fifty-three percent of patients fulfilled the criteria for the metabolic syndrome and $24 \%$ of controls $(P=0.003)$. After adjustment for weight, height and serum concentrations of free $T_{4}$ and DHEAS, the odds ratio for the metabolic syndrome was 3.3 (95\% CI 1.1-9.4, $P=0.03$ ).

\section{Genetics}

All the SNPs were in Hardy-Weinberg equilibrium (HWE) except for the NR3C1 Bcl1 polymorphism in the patient group ( $P=0.02$; Table 4$)$. The genotyping success rate ranged between 98 and 100\%.

After adjustments for age, weight, height, GC treatment and serum concentrations of free $\mathrm{T}_{4}$, IGF1 and DHEAS, patients carrying the CG/GG alleles of the NR3C1 Bcl1 polymorphism had significantly reduced total BMD ( $B-0.05,95 \%$ CI -0.11 to $-0.001, P=0.046)$ and BMD at femur neck $(B-0.09,95 \% \mathrm{CI}-0.18$ to $-0.01, P=0.042)$ (Fig. 2). The patients carrying the TC/CC alleles of the $A B C B 1$ rs1045642 polymorphism had increased abdominal fat mass ( $B$ 1.7, 95\% CI 0.3 to $3.1, P=0.016)$ and decreased ASMM $(B-1.3,95 \%$ CI -2.5 to $-0.02, P=0.019)$. Body composition, BMD and the metabolic syndrome were not associated with any of the remaining SNPs.

\section{Influence of aetiology, duration of active CS and GC replacement therapy on body composition and BMD}

After adjustment for age, weight, height and serum concentrations of free $\mathrm{T}_{4}$, IGF1 and DHEAS, GC replacement therapy was independently associated with reduced total BMD ( $B-0.07,95 \% \mathrm{CI}-0.12$ to $-0.02, P=0.008)$, BMD at lumbar spine $(B-0.13,95 \%$ CI -0.23 to -0.03 , $P=0.016)$ and increased abdominal fat $(B 2.7,95 \%$ CI 0.7 to 4.6, $P=0.009$ ). Aetiology (CD or cortisol-producing adrenal adenoma), duration of active CS and duration in

Table 4 Genotype distribution and minor allele frequencies (MAF) of polymorphisms in glucocorticoid receptor (NR3C1), mineralocorticoid receptor (NR3C2), 11ß-hydroxysteroid dehydrogenase type 1 (HSD11B1) and ATP-binding cassette $B 1$ ( $A B C B 1)$ genes in patients with Cushing's syndrome in remission and controls matched for age, gender and educational level.

\begin{tabular}{|c|c|c|c|c|c|c|}
\hline & & Allele & Patients & MAF & Controls & MAF \\
\hline \multirow[t]{6}{*}{ NR3C1 } & Bcl1 (rs41423247) & $\mathrm{CC}$ & 13 & 0.41 & 17 & 0.40 \\
\hline & & CG & 31 & & 26 & \\
\hline & & GG & 4 & & 7 & \\
\hline & A3669G (rs6198) & AA & 36 & 0.13 & 40 & 0.10 \\
\hline & & AG & 13 & & 10 & \\
\hline & & GG & 0 & & 0 & \\
\hline \multirow[t]{3}{*}{ NR3C2 } & I180V (rs5522) & AA & 43 & 0.05 & 39 & 0.10 \\
\hline & & AG & 5 & & 10 & \\
\hline & & GG & 0 & & 0 & \\
\hline \multirow[t]{3}{*}{ HSD11B1 } & rs11119328 & $\mathrm{CC}$ & 32 & 0.19 & 32 & 0.19 \\
\hline & & CA & 14 & & 15 & \\
\hline & & AA & 2 & & 2 & \\
\hline \multirow[t]{3}{*}{$A B C B 1$} & rs1045642 & $\mathrm{TT}$ & 21 & 0.34 & 19 & 0.42 \\
\hline & & $\mathrm{TC}$ & 21 & & 20 & \\
\hline & & $\mathrm{CC}$ & 6 & & 11 & \\
\hline
\end{tabular}



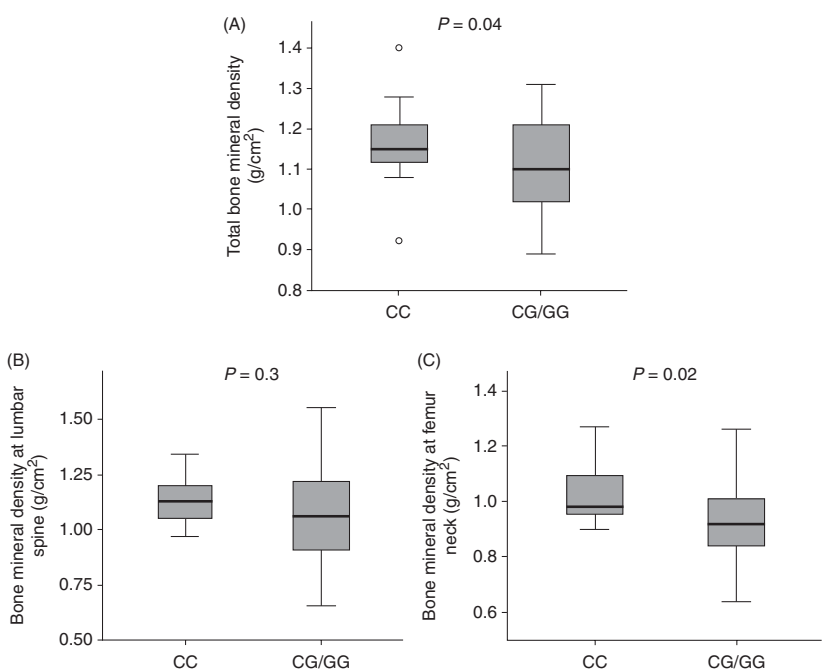

\section{Figure 2}

Box plots showing $(A)$ total bone mineral density (BMD),

(B) BMD at lumbar spine and (C) BMD at femur neck in patients with Cushing's syndrome in remission with CC (WT) and CG/GG (variant carriers) of the $\mathrm{BCl} 1$ polymorphism in the glucocorticoid receptor gene (NR3C1).

remission were not associated with total fat mass, abdominal fat mass, LBM, ASMM, BMD or the metabolic syndrome (Supplementary Table 1, see section on supplementary data given at the end of this article).

\section{Discussion}

This study demonstrates that women with CS in long-term remission have increased abdominal fat mass compared with healthy subjects, which is independently associated with GC replacement and a common polymorphism in the GC transmembrane transporter gene $A B C B 1$. The study also demonstrates that ongoing GC replacement and a common polymorphism in the GC receptor gene are associated with adverse skeletal health in patients with CS in long-term remission.

Adipose tissue mass decreases after treatment for CS $(4,7,8,9,10)$, but whether complete normalisation occurs at long-term follow-up is not fully explored. One previous cross-sectional study found an increased total and abdominal fat mass in patients with CS after a mean time of 11 years in remission in comparison with age-, gender- and BMI-matched controls (11). Our results also indicate that the central obesity associated with long-term hypercortisolism in CS is not completely reversible after treatment. Previous studies on the reversibility of reduced
LBM and skeletal muscle mass have demonstrated either unchanged $(4,8,9,10)$ or reduced LBM after treatment (7, 11). In our study, after adjustment for various confounders, no difference in skeletal muscle mass was observed between patients and controls.

In contrast to our hypothesis, no significant reduction in BMD was seen in the patients. Our results are in accordance with a previous study where BMD at femur neck, lumbar spine and total body was reported to be normal in 18 patients with CS in remission for 6 years (1). On the contrary, in a further study on 37 women with CS in remission for 6 years, BMD was decreased compared with matched controls (15). Interestingly, in that study, duration of GC replacement after treatment for CS was independently associated with reduced BMD at lumbar spine. A similar association was observed in our study, i.e., GC replacement therapy was independently associated with reduced total $\mathrm{BMD}$ and $\mathrm{BMD}$ at lumbar spine, probably explained by the fact that the effects of GCs on the skeletal tissue is most prominent on trabecular bone such as in the lumbar spine (27). The median hydrocortisone dose used in the GC-treated patients in our study was $25 \mathrm{mg} /$ day. This indicates that GC-insufficient patients, at least some of them, received supraphysiological doses that may explain the worse overall outcome in this subgroup. The potential relationship between GC doses and outcome was, however, not possible to analyse due to the relatively small number of patients.

Cardiovascular risk profile improves after treatment for CS $(28,29)$. However, 1 year after treatment many patients still have central obesity, hypertension, dyslipidaemia and IGT or diabetes (29). Even at long-term followup atherosclerotic plaques (30), coronary artery disease (31) and acute myocardial infarction are more frequently observed in CS patients than in controls (32). The findings of this study with lower HDL-cholesterol levels, higher TG levels and increased prevalence of the metabolic syndrome are in line with these previous observations.

To our knowledge, this is the first study analysing the influence of polymorphism in genes important for GC sensitivity, metabolism and transport on body composition and BMD in patients with CS in remission. In our study, the Bcl1 polymorphism in the GC receptor gene was associated with reduced BMD in total body and femur neck, which is in line with a study of patients with active CS (17) and other studies demonstrating increased GC sensitivity in subjects carrying this genotype $(33,34,35)$. A common polymorphism (rs1045642) in the $A B C B 1$ gene was recently found to be associated with reduced bone mass in patients with Addison's disease (22). The gene 
encodes for a transport protein that is important for efflux of intracellular GC (36). In our study, this polymorphism was found to be independently associated with increased abdominal fat mass and reduced skeletal muscle mass, but not reduced BMD.

A surprising finding was that the NR3C1 Bcl1 polymorphism, analysed using TaqMan SNP genotyping, in the patient cohort was not in HWE. The association between reduced BMD and Bcl1 should therefore be interpreted with caution (37). The genotyping success rate was $98 \%$ and no unclear clustering was observed that could explain this deviation from HWE. This and that the deviation from HWE were not observed in the control group argues against a technical error during the analytical procedure. Interestingly, a similar finding has been observed previously (18). One can therefore speculate whether this genetic variant is associated with the development of the CS itself.

This study has limitations. The controls were not matched for weight or BMI, instead adjustments for weight and height were made in the statistical analysis. Although we did adjust for these and several other variables in the statistical analysis, there may still be other factors that may influence our results such as the quality of the sex hormone replacement, the duration of GH deficiency initiated before $\mathrm{GH}$ replacement and the vitamin D status. Another limitation is that we only included women in the study. It would have been interesting to see whether there were differences between men and women with CS in remission as has been shown in patients with active disease (38). Also, we included both patients with CD and cortisol-producing adenomas. Patients with cortisol-producing adrenal adenomas have reduced BMD at lumbar spine (39) and a better cardiovascular outcome than patients with CD (29). We could not show such differences, but the number of patients with cortisol-producing adrenal adenomas was few. Finally, the associations between numerous variables were analysed. The results must therefore be interpreted with caution because some of the significant findings may be a finding by chance, i.e. a type 1 error.

In conclusion, at long-term follow-up, women with CS in remission have increased abdominal fat mass that is independently associated with GC replacement and a common polymorphism in the $A B C B 1$ gene, a gene encoding a transport protein important for efflux of intracellular GC. BMD on the other hand is not different from healthy individuals at a long-term follow-up. However, GC dependency and the common NR3C1 Bcl1 polymorphism in the GC receptor gene are independently associated with reduced BMD in patients in remission.
Supplementary data

This is linked to the online version of the paper at http://dx.doi.org/10.1530/ EJE-14-0747.

\section{Declaration of interest}

O Ragnarsson, C A M Glad, R Bergthorsdottir, E G Almqvist, E Ekerstad, $H$ Widell and B Wängberg have nothing to declare. G Johannsson is consultant for Viropharma and Astra Zeneca and has received lecture fees from Novo Nordisk, Eli Lilly, Merck Serono, Otsuka and Pfizer.

\section{Funding}

This project has received financial support from the Swedish federal government under the LUA/ALF agreement and The Health \& Medical Care Committee of the Regional Executive Board, Region Västra Götaland.

\section{Acknowledgements}

The authors thank Ann-Charlotte Olofsson, Jenny Tiberg, Annika Alklind and their colleagues at the Centrum for Endocrinology and Metabolism for skilful technical support, as well as all patients and controls for their participation. They thank the Mutation Analysis Facility at the Karolinska University Hospital for the Sequenom part of this work; especially Malin Linde, Päivi Kiviluoma and Kristina Duvefelt.

\section{References}

1 Kristo C, Jemtland R, Ueland T, Godang K \& Bollerslev J. Restoration of the coupling process and normalization of bone mass following successful treatment of endogenous Cushing's syndrome: a prospective, long-term study. European Journal of Endocrinology $2006 \mathbf{1 5 4}$ 109-118. (doi:10.1530/eje.1.02067)

2 Vestergaard P, Lindholm J, Jorgensen JO, Hagen C, Hoeck HC, Laurberg P, Rejnmark L, Brixen K, Kristensen LO, Feldt-Rasmussen U et al. Increased risk of osteoporotic fractures in patients with Cushing's syndrome. European Journal of Endocrinology 2002146 51-56. (doi:10.1530/eje.0.1460051)

3 Geer EB, Shen W, Gallagher D, Punyanitya M, Looker HC, Post KD \& Freda PU. MRI assessment of lean and adipose tissue distribution in female patients with Cushing's disease. Clinical Endocrinology 201073 469-475. (doi:10.1111/j.1365-2265.2010.03829.x)

4 Pirlich M, Biering H, Gerl H, Ventz M, Schmidt B, Ertl S \& Lochs H. Loss of body cell mass in Cushing's syndrome: effect of treatment. Journal of Clinical Endocrinology and Metabolism 200287 1078-1084. (doi:10.1210/jcem.87.3.8321)

5 Burt MG, Gibney J \& Ho KK. Characterization of the metabolic phenotypes of Cushing's syndrome and growth hormone deficiency: a study of body composition and energy metabolism. Clinical Endocrinology 200664 436-443. (doi:10.1111/j.1365-2265. 2006.02488.x)

6 Mayo-Smith W, Hayes CW, Biller BM, Klibanski A, Rosenthal H \& Rosenthal DI. Body fat distribution measured with CT: correlations in healthy subjects, patients with anorexia nervosa, and patients with Cushing syndrome. Radiology 1989170 515-518. (doi:10.1148/ radiology.170.2.2911678)

7 Geer EB, Shen W, Strohmayer E, Post KD \& Freda PU. Body composition and cardiovascular risk markers after remission of Cushing's disease: a prospective study using whole-body MRI. Journal of Clinical Endocrinology and Metabolism 201297 1702-1711. (doi:10.1210/jc.2011-3123) 
8 Ueland T, Kristo C, Godang K, Aukrust P \& Bollerslev J. Interleukin-1 receptor antagonist is associated with fat distribution in endogenous Cushing's syndrome: a longitudinal study. Journal of Clinical Endocrinology and Metabolism 200388 1492-1496. (doi:10.1210/jc.2002021030)

9 Burt MG, Gibney J \& Ho KK. Protein metabolism in glucocorticoid excess: study in Cushing's syndrome and the effect of treatment. American Journal of Physiology. Endocrinology and Metabolism 2007292 E1426-E1432. (doi:10.1152/ajpendo.00524.2006)

10 Lonn L, Kvist H, Ernest I \& Sjostrom L. Changes in body composition and adipose tissue distribution after treatment of women with Cushing's syndrome. Metabolism 199443 1517-1522. (doi:10.1016/ 0026-0495(94)90010-8)

11 Barahona MJ, Sucunza N, Resmini E, Fernandez-Real JM, Ricart W, Moreno-Navarrete JM, Puig T, Farrerons J \& Webb SM. Persistent body fat mass and inflammatory marker increases after long-term cure of Cushing's syndrome. Journal of Clinical Endocrinology and Metabolism 200994 3365-3371. (doi:10.1210/jc.2009-0766)

12 Hermus AR, Smals AG, Swinkels LM, Huysmans DA, Pieters GF, Sweep CF, Corstens FH \& Kloppenborg PW. Bone mineral density and bone turnover before and after surgical cure of Cushing's syndrome. Journal of Clinical Endocrinology and Metabolism 199580 2859-2865. (doi:10.1210/jcem.80.10.7559865)

13 Futo L, Toke J, Patocs A, Szappanos A, Varga I, Glaz E, Tulassay Z, Racz K $\&$ Toth M. Skeletal differences in bone mineral area and content before and after cure of endogenous Cushing's syndrome. Osteoporosis International 2008 19 941-949. (doi:10.1007/s00198-007-0514-x)

14 Kawamata A, Iihara M, Okamoto T \& Obara T. Bone mineral density before and after surgical cure of Cushing's syndrome due to adrenocortical adenoma: prospective study. World Journal of Surgery 200832 890-896. (doi:10.1007/s00268-007-9394-7)

15 Barahona MJ, Sucunza N, Resmini E, Fernandez-Real JM, Ricart W, Moreno-Navarrete JM, Puig T, Wagner AM, Rodriguez-Espinosa J, Farrerons J et al. Deleterious effects of glucocorticoid replacement on bone in women after long-term remission of Cushing's syndrome. Journal of Bone and Mineral Research 200924 1841-1846. (doi:10.1359/ jbmr.090505)

16 van Rossum EF \& Lamberts SW. Polymorphisms in the glucocorticoid receptor gene and their associations with metabolic parameters and body composition. Recent Progress in Hormone Research 200459 333-357. (doi:10.1210/rp.59.1.333)

17 Szappanos A, Patocs A, Toke J, Boyle B, Sereg M, Majnik J, Borgulya G, Varga I, Liko I, Racz K et al. BclI polymorphism of the glucocorticoid receptor gene is associated with decreased bone mineral density in patients with endogenous hypercortisolism. Clinical Endocrinology 2009 71 636-643. (doi:10.1111/j.1365-2265.2009.03528.x)

18 Trementino L, Appolloni G, Concettoni C, Cardinaletti M, Boscaro M \& Arnaldi G. Association of glucocorticoid receptor polymorphism A3669G with decreased risk of developing diabetes in patients with Cushing's syndrome. European Journal of Endocrinology 2012166 35-42. (doi:10.1530/EJE-11-0722)

19 DeRijk RH, Wust S, Meijer OC, Zennaro MC, Federenko IS, Hellhammer DH, Giacchetti G, Vreugdenhil E, Zitman FG \& de Kloet ER. A common polymorphism in the mineralocorticoid receptor modulates stress responsiveness. Journal of Clinical Endocrinology and Metabolism 200691 5083-5089. (doi:10.1210/jc.2006-0915)

20 Dekker MJ, Tiemeier H, Luijendijk HJ, Kuningas M, Hofman A, de Jong FH, Stewart PM, Koper JW \& Lamberts SW. The effect of common genetic variation in 11ß-hydroxysteroid dehydrogenase type 1 on hypothalamic-pituitary-adrenal axis activity and incident depression. Journal of Clinical Endocrinology and Metabolism 201297 E233-E237. (doi:10.1210/jc.2011-0601)

21 Martinez F, Mansego ML, Escudero JC, Redon J \& Chaves FJ. Association of a mineralocorticoid receptor gene polymorphism with hypertension in a Spanish population. American Journal of Hypertension 200922 649-655. (doi:10.1038/ajh.2009.39)
22 Lovas K, Gjesdal CG, Christensen M, Wolff AB, Almas B, Svartberg J, Fougner KJ, Syversen U, Bollerslev J, Falch JA et al. Glucocorticoid replacement therapy and pharmacogenetics in Addison's disease: effects on bone. European Journal of Endocrinology 2009160 993-1002. (doi:10.1530/EJE-08-0880)

23 Ragnarsson O, Glad C, Berglund P, Bergthorsdottir R, Eder DN \& Johannsson G. Common genetic variants in the glucocorticoid receptor and the 11ß-hydroxysteroid dehydrogenase type 1 genes influence long-term cognitive impairments in patients with Cushing's syndrome in remission. Journal of Clinical Endocrinology and Metabolism 201499 E1803-E1807. (doi:10.1210/jc.2014-1906)

24 Ragnarsson O, Berglund P, Eder DN \& Johannsson G. Long-term cognitive impairments and attentional deficits in patients with Cushing's disease and cortisol-producing adrenal adenoma in remission. Journal of Clinical Endocrinology and Metabolism 201297 E1640-E1648. (doi:10.1210/jc.2012-1945)

25 Kim J, Heshka S, Gallagher D, Kotler DP, Mayer L, Albu J, Shen W, Freda PU \& Heymsfield SB. Intermuscular adipose tissue-free skeletal muscle mass: estimation by dual-energy X-ray absorptiometry in adults. Journal of Applied Physiology 200497 655-660. (doi:10.1152/ japplphysiol.00260.2004)

26 Zimmet P, Magliano D, Matsuzawa Y, Alberti G \& Shaw J. The metabolic syndrome: a global public health problem and a new definition. Journal of Atherosclerosis and Thrombosis 200512 295-300. (doi:10.5551/ jat.12.295)

27 Toth M \& Grossman A. Glucocorticoid-induced osteoporosis: lessons from Cushing's syndrome. Clinical Endocrinology 201379 1-11. (doi:10.1111/cen.12189)

28 Faggiano A, Pivonello R, Spiezia S, De Martino MC, Filippella M, Di Somma C, Lombardi G \& Colao A. Cardiovascular risk factors and common carotid artery caliber and stiffness in patients with Cushing's disease during active disease and 1 year after disease remission. Journal of Clinical Endocrinology and Metabolism 200388 2527-2533. (doi:10.1210/jc.2002-021558)

29 Giordano R, Picu A, Marinazzo E, D'Angelo V, Berardelli R, Karamouzis I, Forno D, Zinna D, Maccario M, Ghigo E et al. Metabolic and cardiovascular outcomes in patients with Cushing's syndrome of different aetiologies during active disease and 1 year after remission. Clinical Endocrinology 2011 75 354-360. (doi:10.1111/j.1365-2265.2011.04055.x)

30 Colao A, Pivonello R, Spiezia S, Faggiano A, Ferone D, Filippella M, Marzullo P, Cerbone G, Siciliani M \& Lombardi G. Persistence of increased cardiovascular risk in patients with Cushing's disease after five years of successful cure. Journal of Clinical Endocrinology and Metabolism 199984 2664-2672. (doi:10.1210/jcem.84.8.5896)

31 Barahona MJ, Resmini E, Vilades D, Pons-Llado G, Leta R, Puig T \& Webb SM. Coronary artery disease detected by multislice computed tomography in patients after long-term cure of Cushing's syndrome. Journal of Clinical Endocrinology and Metabolism 201398 1093-1099. (doi:10.1210/jc.2012-3547)

32 Dekkers OM, Horvath-Puho E, Jorgensen JO, Cannegieter SC, Ehrenstein V, Vandenbroucke JP, Pereira AM \& Sorensen HT. Multisystem morbidity and mortality in Cushing's syndrome: a cohort study. Journal of Clinical Endocrinology and Metabolism 2013 98 2277-2284. (doi:10.1210/jc.2012-3582)

33 Voorhoeve PG, van den Akker EL, van Rossum EF, Koper JW, van Mechelen W, Lamberts SW \& Delemarre-van de Waal HA. Glucocorticoid receptor gene variant is associated with increased body fatness in youngsters. Clinical Endocrinology 200971 518-523. (doi:10.1111/j.1365-2265.2009.03538.x)

34 Kuningas M, Mooijaart SP, Slagboom PE, Westendorp RG \& van Heemst D. Genetic variants in the glucocorticoid receptor gene (NR3C1) and cardiovascular disease risk. The Leiden 85-plus Study. Biogerontology 20067 231-238. (doi:10.1007/ s10522-006-9021-2)

35 Giordano R, Marzotti S, Berardelli R, Karamouzis I, Brozzetti A, D'Angelo V, Mengozzi G, Mandrile G, Giachino D, Migliaretti G et al. 
BCII polymorphism of the glucocorticoid receptor gene is associated with increased obesity, impaired glucose metabolism and dyslipidaemia in patients with Addison's disease. Clinical Endocrinology 201277 863-870. (doi:10.1111/j.1365-2265.2012.04439.x)

36 Ueda K, Okamura N, Hirai M, Tanigawara Y, Saeki T, Kioka N, Komano T \& Hori R. Human P-glycoprotein transports cortisol, aldosterone, and dexamethasone, but not progesterone. Journal of Biological Chemistry 1992267 24248-24252.

37 Esser C \& Tomluk J. Reporting Hardy-Weinberg tests in case-control studies: reasons for caution but not for panic reactions. Journal of
Investigative Dermatology 2005124 1082-1083. (doi:10.1111/ j.0022-202X.2005.23709.x)

38 Pecori Giraldi F, Moro M \& Cavagnini F. Gender-related differences in the presentation and course of Cushing's disease. Journal of Clinical Endocrinology and Metabolism 200388 1554-1558. (doi:10.1210/ jc.2002-021518)

39 Minetto M, Reimondo G, Osella G, Ventura M, Angeli A \& Terzolo M. Bone loss is more severe in primary adrenal than in pituitary-dependent Cushing's syndrome. Osteoporosis International 200415 855-861. (doi:10.1007/s00198-004-1616-3)

Received 1 September 2014

Revised version received 30 September 2014

Accepted 6 October 2014 